\title{
Procedures of methodological triangulation in sociolinguistic research on multilingualism
}

\author{
Georges Lüdi, Katharina Höchle and Patchareerat \\ Yanaprasart
}

\section{Introduction}

At the moment of writing the proposal for the DYLAN project in 2006, Anne-Claude Berthoud, François Grin and Georges Lüdi did not feel at ease when reviewing the existing literature on European multilingualism. For example, many interesting studies dealt with the territorial and demographic distribution of minority languages, but without identifying the real language competences of the populations. The analysis of questionnaires about language needs in the working world was completely independent of studies on processes of majoration/minoration in the oral interaction during meetings. The significance of the concept "mother tongue" in demolinguistic studies was not analysed in terms of identity value or communicative use. What informants told the researchers about their language practice was taken for granted and not questioned with reference to what really happens (and what tape recordings would show). Consequently, "additive" concepts of multilingualism (a person speaks one or the other language in a specific configuration) were far more dominant than "integrated" ones. We felt the main reason for these deficits might come from the focusing of a monomethodological approach of many studies on one or the other of different dimensions: (1) actual language practices; (2) social representations of multilingualism and linguistic diversity, as revealed through discourse; (3) the language policies of states or other public bodies and the language management of private-sector companies; and finally (4) the linguistic context, or "language environment" in which agents operate. We decided to spell these four dimensions out as analytical cornerstones of our proposal and identified an added value within the DYLAN project ${ }^{1}$ in the analysis of the multiple relations within this four-dimensional scheme. For example, data on language needs and language practices collected by questionnaires in companies or with decision makers would not be taken for granted, but contextualised and analysed as discursive constructions that can complement, but also force us to reinterpret statistical figures. In the proposal (cf. a 
short version in Berthoud 2009), we also pointed out that no dimension should a priori be assumed to have epistemological or phenomenological precedence over any other. This applies, by way of consequence, to the interrelations between them. Thus, a multimethodological approach not only means combining different facets; the resulting global view is more the sum of its parts. For example, representations about multilingualism influence policies and strategies regarding multilingualism; similarly, the ways in which a given linguistic environment is perceived by social actors may influence their representations about multilingualism; normally, each of these dimensions is analysed with particular methods, but only a multimethodological approach can give an account of the relations between them.

These considerations shall be applied in this paper to one of the most frequently asked questions about multilingualism in Switzerland; this question concerns the use of English, sometimes called the fifth national language (Watts and Murray 2001). It was one of the research questions subjacent to Iwar's and my analysis of the Swiss national census Swiss national census 1990 and 2000 (Lüdi, Werlen, and Franceschini et al. 1997; Lüdi and Werlen 2005 et al.). In the following, we will try to illustrate how the combination of methodologies that were used in the Basel DYLAN team may help to answer the question about the significance of English in contrast to German, French, Italian, Romansh, and other languages in Switzerland (Sections 2-6) and what might be the added value if we combine them (Section 7). In doing so, we will focus on the working world exclusively and mainly on the region of Basel where we did most of our fieldwork.

\section{Analysis of legal documents}

First, one could try to answer our key question on the basis of legal discourse. Art. 4 of the Swiss Federal Constitution (Federal Constitution of the Swiss Confederation of the $18^{\text {th }}$ of April, 1999) names German, French, Italian, and Romansh as the national languages and Art. 70 says that the official languages of the Confederation shall be German, French and Italian and that Romansh shall also be an official language of the Confederation when communicating with persons who speak Romansh. English is not mentioned at all and thus does not have any official status. However, the very fact that since 2001, there is an English version of the Constitution on the web indicates that the social reality might be different. ${ }^{2}$ Why, if not, should Felix Gutzwiller, a member of the National Council, have proposed that the Federal Government should adopt English as working language in 
addition to the official languages on the $28^{\text {th }}$ of November, 2007? For example, English plays an important role in the educational systems' regulations of foreign languages at school. Indeed, the Swiss Language Law 2007 (Bundesgesetz über die Landessprachen und die Verständigung zwischen den Sprachgemeinschaften [Sprachengesetz, SpG] vom 5. Oktober 2007) does not make any explicit reference to English as a subject which is taught in school; the wording in Art. 15.3 is instead: "within the framework of their competency, the Confederation and the cantons commit themselves to set up a foreign language education providing for pupils' competences in at least a second national language and an additional foreign language at the end of compulsory school". ${ }^{3}$ The matter is however spelled out in the documents authored by the Conference of Cantonal Ministers of Education. In a decision dated March 25, 2004 (http://www.edk.ch/dyn/13673.php), for example, the list of common goals proclaimed for all cantons explicitly includes a knowledge of English ("pupils develop competences in the English language"4) the teaching of which shall start in the $3^{\text {rd }}$ or $5^{\text {th }}$ grade of Primary School. Other examples of language regulations concerning English at the federal level are the internal rules of the Swiss National Foundation that mostly insists on English for the writing of research proposals, and the fact that the great majority of master programs in both the Swiss Federal Institute of Technology in Zurich and Lausanne are offered in English only. ${ }^{5}$

\section{The demolinguistic approach}

Second, a demographic approach is considered useful in order to measure the increasing role of English in Switzerland's working world. The figures from the Swiss Federal Census of 1990 and 2000 confirm that immigration of native speakers is not the main reason for this. In $1990,8.9 \%$ of the population declared a non-national language as their dominant language and in 2000, they were 9\%. Among the latter, English plays a marginal role while other languages like Serbo-Croatian or Albanian, whithout any major role in the country, are much more frequently declared as L1: 
Table 1. Proportion of the 15 most frequent non-national languages in the Swiss population (in \% and absolute figures), 2000

\begin{tabular}{lrrlrr}
\hline & in \% absolute & & \multicolumn{2}{c}{ in \% absolute } \\
\hline Serbian/Croatian & 1,4 & $103^{\prime} 350$ & Arabic & 0,2 & $14^{\prime} 345$ \\
\hline Albanian & 1,3 & $94^{\prime} 937$ & Dutch & 0,2 & $11^{\prime} 840$ \\
\hline Portuguese & 1,2 & $89^{\prime} 527$ & Russian & 0,1 & 9'003 \\
\hline Spanish & 1,1 & $77^{\prime} 506$ & Chinese & 0,1 & $8^{\prime} 279$ \\
\hline English & 1,0 & $7^{\prime} 425$ & Thai & 0,1 & 7'569 \\
\hline Turkish & 0,6 & $44^{\prime} 523$ & Kurdish & 0,1 & 7'531 \\
\hline Tamil & 0,3 & $21^{\prime} 816$ & Macedonian & 0,1 & 6415 \\
\hline
\end{tabular}

Source: Swiss Federal Census, BFS

The level of frequency of English as a language spoken in the family is not much higher and did not increase much from 1990 to 2000 either $(3.4 \%$ in $1990,4.4 \%$ in 2000). The figures for the languages spoken at work, however, explain the growing awareness of the educational authorities of the importance of English. In all language territories, even though the local language prevails massively as the language used at the workplace, the second national language has been overpassed by the use of English that increased dramatically between 1990 and 2000 except in the Italianspeaking part of Switzerland:

Table 2. Frequent use of the national languages and English in the working population in Switzerland, by language region (in \%), 2000

\begin{tabular}{lllll}
\hline & $\begin{array}{l}\text { Local national } \\
\text { language }\end{array}$ & $\begin{array}{l}\text { Second national } \\
\text { language }\end{array}$ & $\begin{array}{l}\text { Third national } \\
\text { language }\end{array}$ & English \\
\hline German & $98,0 \%$ & $19,7 \%$ (French) & $11,1 \%$ (Italian) & $23,4 \%$ \\
\hline French & $97,9 \%$ & $15,4 \%$ (German) & $6,8 \%$ (Italian) & $17,7 \%$ \\
\hline Italian & $98,6 \%$ & $22.0 \%$ (German) & $16,9 \%$ (French) & $11,0 \%$ \\
\hline
\end{tabular}

Source: Swiss Federal Census, BFS

The use of English at the workplace is not evenly distributed among the socio-professional classes, nor is it among the regions. There are tremendous differences, e.g. between members of liberal professions in Germanspeaking Switzerland (54,5\%) and unskilled workers in the Italian-speaking territory $(2,7 \%)$, but also between the cantons $(35,9 \%$ in Basel-City, 5,0\% in Jura). As the following map shows, it is particularly frequent in the business centers in the metropolitan regions of Basel, Zurich-Zug and Geneva: ${ }^{6}$ 
Map 1. Proportion of English spoken at work in Switzerland, by district, 2000

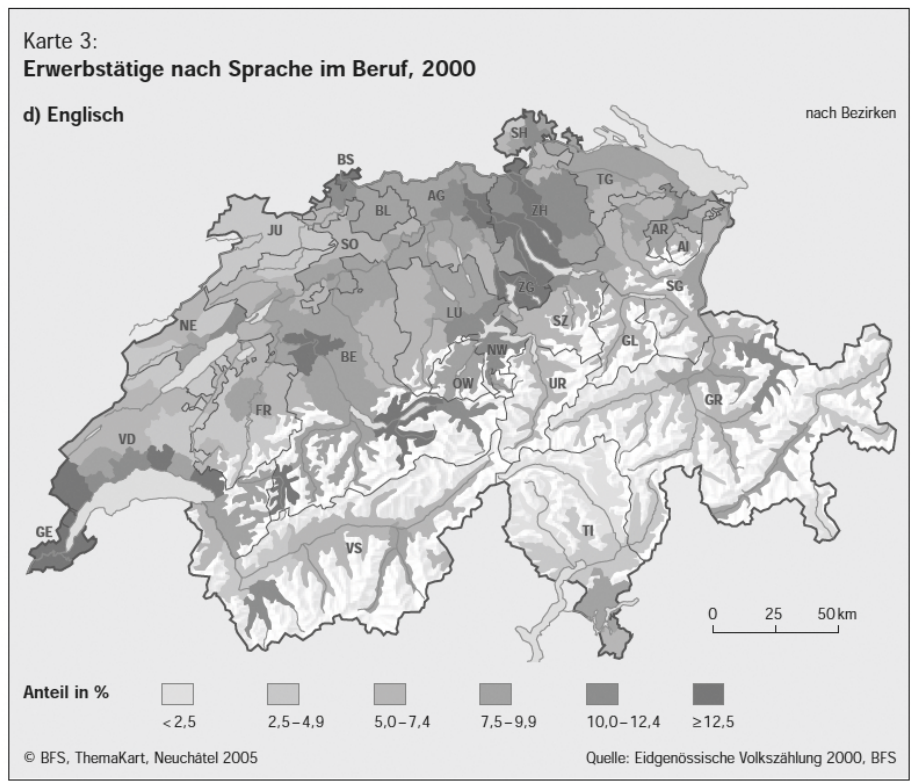

According to a study run by the NFP 56, English is rated as the most useful foreign language by $86 \%$ of informants ( $92 \%$ in the German-speaking, $88 \%$ in the French-speaking and $77 \%$ in the Italian-speaking region) (http://www.snf.ch/D/NewsPool/Seiten/mm_08mar03.aspx).

A last quantitative result at the end of this section: We have measured the linguistic integration of the main groups of speakers of non-national languages by calculating the percentage of speakers declaring one of these languages as L1 and declaring the local language as one of their family languages.

Table 3. Integration of the local national language in the family repertoire in Switzerland, by declared L1 and language region (in \%), 1990 and 2000

\begin{tabular}{ccccccccc}
\hline \multicolumn{1}{c}{ L1 } & \multicolumn{2}{c}{ Spanish } & \multicolumn{2}{c}{ Portuguese } & \multicolumn{2}{c}{ Turkish } & \multicolumn{2}{c}{ English } \\
\hline $\begin{array}{c}\text { Language } \\
\text { region }\end{array}$ & 1990 & 2000 & 1990 & 2000 & 1990 & 2000 & 1990 & 2000 \\
\hline German & 25,4 & 36,6 & 18,7 & 24,0 & 28,8 & 31,7 & 58,8 & 50,9 \\
\hline French & 47,1 & 55,8 & 36,0 & 43,6 & 38,5 & 38,6 & 53,3 & 51,4 \\
\hline Italian & 54,7 & 72,1 & 40,8 & 54,5 & 35,3 & 38,6 & 45,4 & 55,4 \\
\hline
\end{tabular}

Source: Swiss Federal Census, BFS 
With values between 50,9\% and 55,4\% in 2000, the score of English is not particularly low. However (except in the Italian-speaking region) the figures for English are the only ones to have decreased between 1990 and 2000, a clear indicator for the growing acceptance of speakers of English using their language not only at work, but also in public, i.e. a lower level of pressure to integrate linguistically felt by Anglophones.

\section{The analysis of the linguistic landscape}

The percentages of speakers speaking a language at work on a daily basis certainly provide significant insights into the use of this language in Switzerland. But the presence of English is also observable in other forms. Modern urban spaces are characterized by a flow of signs (pictures, posters, luminous advertising, road signs, architecture, etc.). A new, vivid approach by sociolinguistics concentrates on the linguistic or semiotic landscape 7 (Rosenbaum et al. 1977, Calvet 1990, Spolsky and Cooper 1991, Landry and Bourhis 1997, Ben-Rafael et al. 2004, Shohamy and Gorter 2008). This methodology was applied to Basel with the aim of getting a comprehensive picture of the sociolinguistic situation in general and the role of English in particular.

As one could guess from preceding research, the dominant language in the streets of Basel is German, the official local language. Throughout the city, road signs, requests and information targeted at postal agents, pedestrians and other groups whithin the population (e.g. signs advertising flats to rent, price labels, stickers prohibiting advertising mail at letterboxes, etc.) are always in German, not only where the producers of the signs belong to the political authorities, but also on private signs, be it in shops, in billboards, ads, etc. Even signers of foreign origin conform to this rule and this without any legal pressure (unilingual signs in languages other than German are legal) - although they sometimes choose to use both languages in multilingual texts (Photo 1). This is, for example, true in the Klybeckstrasse, in the centre of a borough mostly inhabited by immigrants, where 79 out of 85 signs are unilingual German. In contrast, only 76 out of 110 are unilingual German in the Freie Strasse in the historic centre. The second frequent language in Basel's linguistic landscape is neither another frequently used official language of Switzerland (French, Italian), nor one of the major languages of immigration (see table 1 above), but English, with a particular dominance in the historic centre ( 24 out of 110 pictures in the 
Freie Strasse vs. 2 out of 85 in the Klybeckstrasse). The lingua franca among immigrants and with the local population being clearly German, English is used with tourists, in trendy fashion shops and around the railway stations and the airport, sometimes with a symbolic rather than referential function (Photo 2); and languages other than German and English are clearly minorized (see Lüdi 2007 for full results).

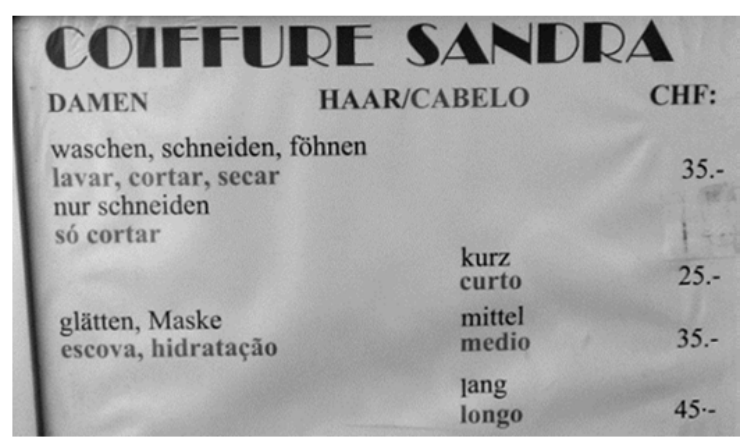

Photo 1

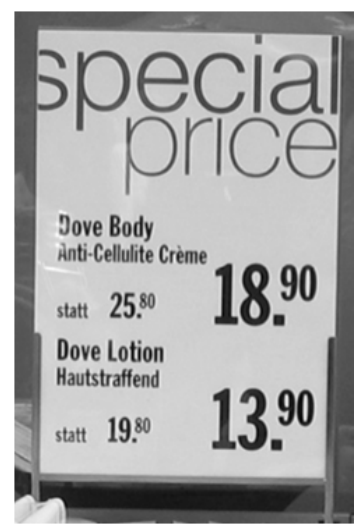

Photo 2

There is, however, a part of the city's linguistic landscape where English plays an even more important role than in the historic centre: the premises of the large international companies (chemical, pharmaceutical and agroindustry, banks, etc.) established in Basel, protected by fences, barbed wire, security agents and chaperonage and thus enjoying a kind of "extraterritoriality". There, English is very present indeed as one would expect from companies declaring it to be their corporate language (Lüdi et al. 2009). But all the signs in the premises are not unilingual English. Many German, bilingual or multilingual tablets attest to a diversified approach to language choice in linguistic landscaping. Indeed, it reflects, in one significant way, the linguistic repertoires of the "scriptors" (a factor called by whom by Backhaus in 2007) and in another their perception of the addressees' repertoires (for whom). Thus, supposing that visitors to $<$ Factory A $>$ in Switzerland speak English, the company decided that all labels in a small museum situated immediately behind the entrance should be in English. Nonetheless, each visitor, or group of visitors, is personally greeted on a video screen above the visitors desk in his or her conjectured language (German for a researcher from Basel University, for example); simultaneously, a spot changing every few seconds welcomes everybody in a large number of 
the world's languages, e. g. Chinese, Japanese, Arabic, Russian, Portuguese, etc. These choices are determined without doubt by a top-down language management: it is the company that welcomes the visitors and tells them: " $<$ Factory $\mathrm{A}>$ is not only a national, but also an international and plurilingual enterprise." In contrast, unilingual German signs on the premises of $<$ Factory $\mathrm{A}>$ refer to a social representation in which most of the collaborators whithin the company are German-speaking (Photo 3). Bilingual panels in $<$ Pharma $\mathrm{A}>$ and $<$ Agro $\mathrm{A}>$ convey a different self-image and suggest a more heterogeneous conception of the two companies' collaborators and visitors respectively, local workers and visitors being addressed in German (sometimes in French), expatriates from all parts of the world as well as international visitors in English (Photo 4). Consequently, different language choices made by mostly anonymous scriptors are to be interpreted as signs of their diversity. As mentioned before, these practices reflect the scriptors' views on the addressees' as well as their own competences and the particular language functions performed by the signs ${ }^{8}$ (cf. also Mondada 2004 : 258 who spoke about "la dimension polyphonique des représentations attribuées à des énonciateurs particuliers").

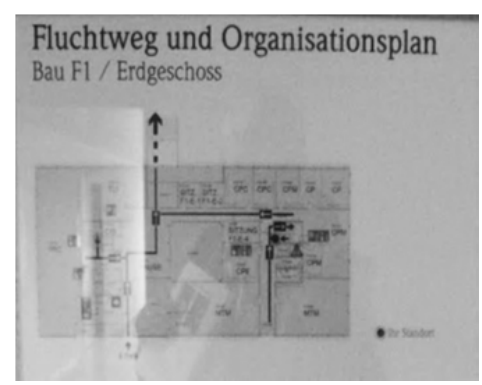

Photo 3. Factory A

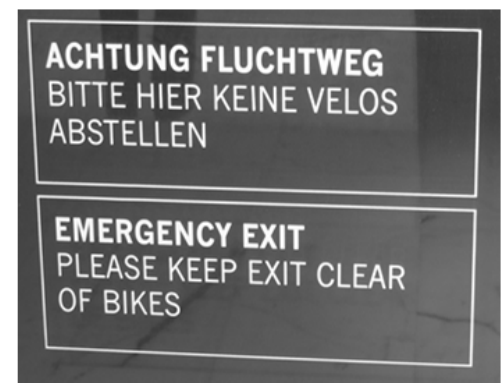

Photo 4. Pharma A

It is noteworthy that scriptors with a bare competence in German (as manifested by the spellings Ture instead of Türe; Verpakungen instead of Verpackungen; the wrong use of capital letters; syntactical errors) nevertheless choose German on the premises of $<$ Pharma $\mathrm{A}>$ and renounce the use of their own languages, but also English, said by the endoxa" to be "the language of $<$ Pharma A $>$ ". They pay no attention to normativity and choose the local lingua franca, German, for messages directed at their fellow workers, assuming that the latter are German speakers or, at the very least, can understand German. 
We referred in two earlier studies (Lüdi et al. 2009, 2010) to a very pragmatic approach to language choice on the premises of $<$ Pharma $A>$ in the domain of safety instructions: the goal of preventing accidents clearly outweighs local traditions - that would privilege German - as well as some managers' preferences for English. In addition, it should also be noted that it is one of the rare cases where French and Italian are preferred to English in multilingual signs. The hypothesis is allowed that the conative and referrential functions (Jakobson 1960) bring scriptors to push up those languages that are really understood by the addressees as, for example, in the case of the - mostly immigrant - workers in charge of filling the liquid gas bottles or the building workers occupied on the premise of $<$ Pharma $\mathrm{A}>$ (Photo 5). In other signs, however, the emotive function seems to dominate with priority given to the self-image the scriptor wants to convey. Thus $<$ Pharma $\mathrm{A}>$ insists on its self-perception as a global company using unilingual English signs wherever communication is not hampered (Photo 6). The same phenomenon can be observed in shop windows in the city that mostly give the most relevant information in German. But in contrast to the latter case, $<$ Pharma $\mathrm{A}>$ also has a significant number of collaborators who do not read German, thus requiring many bilingual signs with parallel texts in German and English.
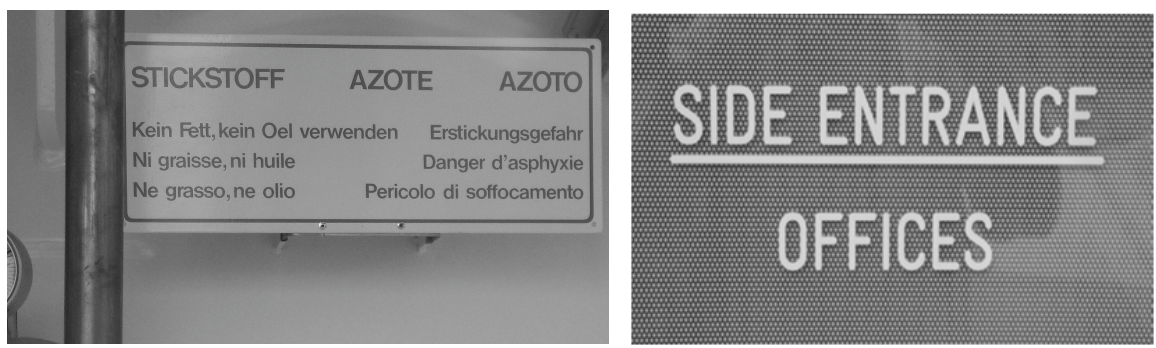

Photos 5 and 6. Pharma A

Without going into further details, we hope we have demonstrated the usefulness of the analysis of the linguistic landscape, not only as a relevant form of language practice, but also as an important source of information about the signers' repertoires and their representations of those of their addressees. 


\section{Interactional linguistics}

Our fourth methodological approach is about oral practices in the working place. Our considerations are grounded in the microanalysis of short sequences spread out over about sixty hours of tape recordings. There were dyadic and polyadic interactions of different kinds comprising meetings, discussion of results in a lab, telephone conferences, small talk during coffee breaks, oral presentations, etc. including self-recordings with clip-on microphones during entire working days. This methodology adds an important dimension to the statistical figures mentioned above. On the one hand, it informs us about the microcontexts and forms of language choices, confirming that the use of English at the workplace is very frequent indeed. On the other hand, the analysis of such sequences sheds light on the fact that not only does the use of English not really exclude other languages (mainly Swiss German, German and French), but that the apparently obvious principles OLON ("one language only") or OLAT ("one language at a time") are often not respected and take second place with respect to ALAST ("all languages at the same time"). In addition:

a) these interactions were rarely endolingual (among native speakers of English), but mostly exolingual (including non native speakers or exclusively among non native speakers); thus, they illustrate what is often called English as lingua franca (ELF) in the literature (for ex. Knapp and Meiercord eds. 2002, House 2003, Seidlhofer 2006, Jenkins 2007, Mauranen and Ranta eds. 2009);

b) most persons participating in these interactions are fluent in English, their level of competence being good or very good, but there are exceptions; the use of ELF excludes the latter or rather converts them into "bystanders" (Goffman 1981, 131ff.);

c) independent of the level of competence of the speakers, these interactions are frequently bi- or multilingual. One the one hand, ELF can be said to be always multilingual in principle, a dynamic form of "languaging" including traces of the speakers' other languages (Pitzl 2009, 315; Böhringer, Hülmbauer and Seidlhofer 2009); on the other hand, explicit forms of multilingual speech including code-switchings or changes of the matrix language allow the participants to exploit their mostly multilingual repertoires in an optimal way. This form of language practice, also called "multilanguaging" or "translanguaging" (Pennycook 2007, García 2007) is particularly frequent in our corpus; three short examples must suffice for the purposes of illustration here. 


\section{Example 1}

$13 \mathrm{BH}$ jetzt wäre ich wahnsinnig froh wir hatten immer gesagt äh (always) I switch no I'd be very happy we had always said ehm

14 in english for a moment (.) we have said always that we'd like to use this a bit

15 informal way jetzt sitzen wir hier so etwas schön geordnet aber wir hatten now we are sitting here kind of properly ordered but we had

16 immer gesagt wo drückt uns der schuh was was was liegt an an was ähm habe always said where does the shoe pinch what what what is pending ehm what

17 ich für gerüchte gehört ähm (.) was beschäftigt mich was müsste man rumours did I hear (.) what bothers me? what should we

18 eigentlich los werden gibt es da irgendetwas (.) ich finde es irgendwie etwas get shot of? is there anything (.) I think it is in a way

19 schwierig so formell aufgestellt zu sein dafür aber gibt es etwas was was difficult to be so formally aligned for that purpose but is there something that

20 euch am Herzen Herzen liegt (4 s.) is close to your hearts?

21 WM I would just like to say that informal bit ähm ( $\mathrm{xxx}$ ) yeah I think that if we

22 moved the tables out and sat around both sides we have more contact because

23 this is a bit kind of a board meeting \& ((general laughter))

$24 \&$ and I feel like I'm the head of the board \& this is quite nice

This sequence was recorded during an informal meeting of the HR board of $<$ Public service A>, a common breakfast shortly before Christmas. The majority of the participants is German-speaking, a minority Frenchspeaking. One board member (Wanda M.) is British; she lived in the Suisse romande for many years and became very fluent in French. She understands German without any problem, but prefers to speak English. Despite the philosophy of the company that privileges the national languages, $\mathrm{BH}$, the head of the section, switches to English in a strategy of inclusion in order to make his British colleague feel at ease while all the other participants continue to speak German.

This is entirely different in example 2 , where the language used in the meeting of the editorial board of $<$ Pharma A's $>$ internal magazine changes completely from German to English as soon as the boss, a Canadian (PW), enters the room - and switches back to German as soon as he leaves the room again.

\section{Example 2}

1 SM: =jetzt rein (.) nur (.) aso auch von (.) von der\& now strictly only well also with respect to the

2 \&grafiksprache die mir jetzt zumindest so bekannt ist\& 


\section{graphic language as far as I know}

3 \&dass man halt braun (.) dass man das mit hellen tönen\&

$$
\text { you just combine brown with light shades }
$$

4 \&mischt mit blau[tönen] with blue shades

5 CF: [aaaah]

((the door opens, PW makes his entrance accompanied by comments and a general brouhuha))

6 PW: [ha ha ha ha ha]

7 SM: now it's gett[ing]

8 BK: [ha ha ha ha ha]=

9 PW: the language is [( $\mathrm{xxx})$ once again]

10 SM: [we switch in English]

((general laughter))

11 PW: what a benefit=

$12 \mathrm{SS}$ : =we're only getting started

$13 \mathrm{JK}:$ ((by side)) (xxx)

14 PW: sorry about that again=

$15 \mathrm{CF}$ : =that's great=

16 PW: =yeah i'm sure it's perfect

$17 \mathrm{CF}$ : [what eh]=

[((general laughter $))]$

18 PW: [yeah

$19 \mathrm{CF}$ : =christoph you said we have to use white (.) who says \& $\&$ we have to use white we?

PW's entrance and the subsequent - manifestly habitual - change of language is properly orchestrated with laughter and comments (1. 5-10); PW's excuse (line 14) can be read as a tentative effort to repair any negative consequences directly to his face arising from his enforcement of English.

In the third example, a bilingual participant changes from the default language of a scientific meeting in a laboratory section of $<$ Pharma $\mathrm{A}>$, English, to German not because of the constellation of the participants, but as an auto-facilitating strategy. 8 out of 9 participants are Germanspeaking. In lines 272f., Tatjana, a Polish PhD student, is appeased by a "face flattering act" (Kerbrat-Orecchioni 1992) (dimension of equity) whilst Nina S. (NS) justifies the language change in this context with a higher efficiency of German:

\section{Example 3}


271

272

273

274

275

276

((she rummages around in her papers))

okay ich mach das jetzt einfach in deutsch weil ich weiss dass die okay I will just do it in German because I know that tatjana sehr gut deutsch +versteht und + auch sprechen kann dann Tatjana understands German very well and can also speak it then geht's nämlich schneller (h) for it will take less time ((somebody is laughing)) also wenn man sich die graphiken anschaut (..) wird (..) so if one considers the graphs one

Finally, our last example, from a laboratory of the same section, shows how $\mathrm{JH}$, the head of the lab, a multilingual Moroccan with reduced competences of German, urges his collaborators to speak German and switches to this language from time to time as a means of including members of his lab with precarious competences in English, like Marianne (ML) and Mara (MS), who are lab assistants of Swiss and Hungarian origin respectively:

\section{Example 4}

1 JH maybe Marianne you can summarize in German ya what's eh you did

2 ML: mmh

3 JH: and what you expect

4 ML: mmh (...) also wir haben jetzt das rpmi protokoll (.) aufgemöbelt (.) ehm well we pepped up the rpmi record

5 aufdatiert (.) und zwar haben wir diesen faktor (.) diesen verdünnungs- eh we updated it in fact we added this factor this dilution ehm

6 fakt- correction factor noch reingegeben= fact- correction factor

((some minutes later, still dealing with the same topic))

7 NS: so i think we can write like this with (.) müssen mit einem faktor von we have to [sc. multiplicate] with a factor of

8 ehm=

9 JH: ein komma drei

one point three

10 NS: (...) und dann würd ich den satz dazumachen einfach um zu\& and then I'd add the sentence simply to

$11 \mathrm{JH}:=\mathrm{mmh}=$

12 NS: \&erklären (..) wie es dann zu den auch verschiedenen abkürzungen hier explain how it comes to the different abreviations here

13 kommt weisch so nen correction factor das beinhaltet salzfaktor und you know such a correction factor comprises salt factor and

14 substanzgehalt (.) und dann eben dieser verdünnungsfaktor= the concentration of the substance and then precisely this dilution factor 
15 ML: =jo salz git's jo nüm

$16 \mathrm{JH}:$ maybe then

yes salt doesn't exist anymore ((in Swiss German))

$17 \mathrm{NS}$ : =and then and then the calculation ja

yeah

$18 \mathrm{JH}$ : then here that should be the same (.) you say you explained between

19 brackets it takes äh (.) yeah one thing you could do (.) either

20 you do this nullkomma-fünfsechs milliliter medium without s9 then we zero point five six

21 have one correction factor dilution factor

((much later; towards the end of the meeting, $\mathrm{JH}$ is briefing his team))

$1239 \mathrm{JH}$ then it's very good it's really really good

1240 because then Mara

$1241 \mathrm{MS} \quad$ ((winces)) was müssen wir?

what do we have to do?

$1242 \mathrm{JH}$ kein problem mara ha:: hat eh microkern xxx drei

no problem mara does $\mathrm{m}$. have $\mathrm{xxxx}$ three

1243 oder vier? (.) dann wir braucht nichts mehr or four then we need nothing more

1244 gendata bis september oder oktober gendata until september or october

In contrast to Examples 1 and 2, the formal hierarchy has no impact on language choice here; by switching to German, a language he speaks only with difficulties, JH accommodates himself to his collaborators. When proposing a participation frame, he waives his prerogatives as superior. His code-switching when addressing MS (1. 1240) changes her status from a bystander to an active, ratified hearer.

It is noteworthy that both, NS (Example 3) and JH (Example 4), bring forward the argument of higher efficiency for justifying the partial avoidance of English despite the company's endoxa; NS does it in the interaction itself, $\mathrm{JH}$ in a comment he made on the transcription in an interview later on:

In your daily work, you don't realise how you juggle with the languages. The aim is really to bring the message through and to be efficient. We have no time to waste. ${ }^{10}$

It is not wrong to say that these examples confirm - or at least do not contradict - the predominance of English in these companies. However, it is not "pure" English, and it is absolutely not used exclusively, but in alternation or even together with other languages, mainly the local ones. We will come back to this point in a moment. 


\section{The social representations of the agents}

Of course, JH's utterance does not belong to the interactional analysis, but illustrates the fifth methodological approach that we used in our work: discourse analysis of a large number of semi-directed interviews conducted with key agents and, moreover, of official documents produced by the companies. In doing so, we are looking for the members' shared knowledge, in the case with respect to the role and use of English. It is a topic that is present in most of the interviews. Our Atlas-ti database contains over a hundred statements about English that can be subcategorized into three subtopics. As one would expect, their distribution depends largely on the type of company (international, national and regional companies) in which these statements were gathered.

\subsection{English as corporate language}

This topic comes up frequently among agents of international companies based in Switzerland (in our corpus $<$ Pharma $\mathrm{A}>$, $<$ Agro $\mathrm{A}>,<$ Bank $\mathrm{A}>$ ). "Our corporate language is English" is endoxa, i.e. shared knowledge endorsed by decision-makers or opinion leaders and diffused by intertextual processes throughout the companies, even with employees refractory to English:

generally speaking $<$ Agro $A>$ is predominantly English-oriented, like most multinationals (AA_PER_KB_090129_TR.doc)

$\mathrm{mmh}$, the language of the management is English, 'business language is English' as they say, and this is really the norm in written communication, when something comes from the CEO, from the CFO, for example, than it's normally in English (BA_PER_HG_070228_TR)

Ok, I don't want to sidetrack. It's (important) to mention that English is a dominant language. Two overall dominant languages, English and German. German feels disenfranchised, the German speakers feel disenfranchised in this company (AA_PER_KB_090604_TR.rtf)

We expect the collaborators to move slowly towards one language only, English, for internal communication (PA_MAN_TB_090625_TR.rtf)

I don't want it either, or better: in my head I know I need it, I have to [sc learn it], that's it, but when the moment finaly arrives, I cannot do it. And I also know, I've heard it $\mathrm{x}$ times ${ }^{11}$, English is $<$ Pharma $A>$-language, very well, I think this is very convenient for many people, yeah (PA_LABB_MS_070810) 
It is noteworthy, however, that none of these utterances - and they are representative of our corpus - is claiming a general use of English in an unmodulated way. The restrictions go from ,predominantly“, "the normal case for written language", "a [and not 'the'] dominant language", "particularly when you are abroad", "that we are slowly moving towards" to "I know it would be necessary, but I can't", etc. These examples are typical of the handling of stereotypes: they are mentioned or quoted, but then their range of coverage is restricted (Oesch-Serra and Py 1997).

Some key agents even go further and state measures of diversity management such as the translation of the core messages into the languages of the employees:

With respect to the information for collaborators, it is kind of a struggle I have to go through <in my function [anonymised]>, so languages, the minimum we use is German, French, English; you must always tell it again because those from the holding company put pressure on for everything to be in English, but well I insist upon two national languages so it is always also in German and French, that is the way it is done. (PA_MAN_TB_090625_TR.rtf)

Well sure, the language regions are a big challenge, because we cannot expect that each collaborator in every function automatically speaks English and understands an English presentation sent to him. This means that we frequently ehm take the communication in the intranet, that is a classic case, it is ALWAYS in four languages, that is we formulate a message in one language, send it to the translation services, it is translated into the four, pardon, the three other languages, and then published that way (...) these are of course challenges we have to meet. We cannot do everything in English, it doesn't work. (BA_PER_HG_070228_TR)

KB: And naturally we realised that to be able to drive home to employees across the world the real meaning of this, the real implications and or import of these eight capabilities, drive it home to them in an emotional way, we cannot do it by explaining to them in English, a second language or a third [language.] (...) and we could very easily have said this is for leaders and this is a company where everybody CAN speak English so let, let's give it to them in English. (.) But the depth which is our foundational principle of the cultural alignment (...), which is how is it linked to moving people in deeply resonant ways, (...) it needs to be understood,

GL: In another way than just in a [lingua franca ]

KB: [in another way, yes] in a lingua franca intellectually processing it. (...) And therefore we had it translated (AA_PER_KB_090129_TR.doc)

In other words, we clearly observe a case of polyphony in the endoxa of these companies ${ }^{12}$ as differently stated by their agents, whose images of the 
status of English and other languages respectively are not entirely compatible. Note that diverging statements frequently come from the same person. Some voices insist on the economy of unilingual communication, others on the heterogeneity of the workforce, and still others bring forward arguments of more equity, but also higher creativity and quality of work wherever people can make use of their own language.

\subsection{Which use of English?}

Inspecting the agents' statements about their personal use of English (the following examples come from $<$ Factory $\mathrm{A}>$ and from $<$ Bank $\mathrm{A}>$ ) helps to understand better their answers to the question of their regular use of English at work.

There is definitely a shared knowledge (doxa) that English is important; however, we frequently observe various forms of contextualisation of, i.e. distanciation from the stereotype concerning the own experience. In some cases, the 'frequent use' is attributed to colleagues:

$\mathrm{KH}$ is a lot of English needed in $<$ Factory A $>$ ?

NK I think so, well not me as a design draughtswoman, but the project leaders and the construction engineers more likely (...) also telephone calls with China now that we have opened [sc. a new branch] there, and when they call, it's just English (FA_APR_NKCW_090709_TR.rtf)

In other cases ${ }^{13}$, the use is restricted to some domains, like reading papers, or even to technical terms:

GL: What's the role of English in your daily environment here?

ER : Well, we have a lot of English. For the electronics, you can't change it. All the data sheets are in English, that's it, hence English is also compulsory. And English is also easier than German, I think. (FA_ETU_ER_080204_TR.rtf)

$\mathrm{KH}$ In which situation do you need English here for your work?

CW Well I don't need it at all

NK (h) I just need it on the drawings

$\mathrm{KH}$ Mhm

CW yes, but in fact you always need the same things, isn't it so?

NK not always, no, and from time to time we get emails in English when they come from the general management, they are in English also [so that] \&

$\mathrm{KH}$ [yes]

NK \& everybody can read them, those in Switzerland as well as those in France (FA_APR_NKCW_090709_TR.rtf) 
KH: (4.16) Yeah. How much English do you need for your work here?

AB: (2) Well (.) How shall I say it? So all the data sheets are just in English, so when we construct something or so and have to get information about some component, the data sheets are only in English, well formerly there was also one or the other in German, but now everything has become so international and now it's only in German eh English, yes

$\mathrm{KH}$ : and elsewhere for- for $(\mathrm{xxx})$ oral communication you use mainly German or English or both?

AB: Actually only German. It is (.) very unfrequent that I have to say something in English. (FA_APR_AB_090709_TR.rtf)

The rare communicative events where these employees speak English include occasional phone calls from abroad, contact with visitors and chatting with the cleaning woman.

An anecdote told by the former head of the language division of $<$ Bank A $>$ confirms these findings. After an American board member had complained that the employees in the bank's IT division were not able to sustain a conversation in English - and requested that all of them should prepare and pass the Cambridge Proficiency Exam -, a study mandated by the CEO revealed that less than $10 \%$ had to be fluent in English and that reading competence at a much lower level (A2 - B1) would be sufficient for the majority.

\subsection{Uneasy feelings}

A third collection of utterances refers to the bad feelings felt by some when it was necessary to speak English as an imposed foreign language, even from the perspective of almost accomplished bilinguals.

A mixed group collapses into English. And whether it's the right tactic is an open question. I think it isn't, from a certain perspective, that people who don't speak English proficiently, are not able to get the right airtime, people don't feel comfortable. (AA_PER_KB_090604_TR.rtf)

To translate everything represents additional costs so [to renounce doing it] would be a thing- an economic line of action ehm but this would generate unfairness (PA_MAN_TB_090625_TR.rtf)

She needs to understand the message in the shortest time possible. It's useless to speak English and then I have to explain it again, to tell it again, to wait for somebody to translate, so I try to be a translator myself. So here, it is really to facilitate things, that is to make everyone feel at ease, everyone understands, everyone at the same level, and that is it, efficiency means in fact, immediately, 
when a meeting is finished, everyone already knows the message. (PA_LABB_JH_080118)

In encoding a problem, in perceiving and sensing it, in understanding, you are not collapsing into English. I mean that for me is the key. You're using the native language. Whether it's done by the individual, whether it's done by some group, and that gives insights to the problem. (...) How we can exploit, how we can take advantage of the role of language as I said as a toolkit, that a culture, a country uses, to encode its realities. And using that strategically as a way of positioning multilingualism for competitive advantage, rather than for communication effectiveness. (AA_PER_KB_090129)

And I feel, I mean at a very personal level, I also sometimes feel the need to speak my own language. You observe also with Karim, you observe that he found friends of the same nationality in the company. And then he is really happy. Despite his being really fluent in English, everything is marvellous (...) I speak differently in my own language, more freely, more openly, with more self-confidence and more security. (...) Many ideas get really lost when you choose English in such a situation, because everybody doesn't equally, doesn't feel equally at ease. (AA_PER_MM_100416)

We have tried to argue in other publications (Lüdi et al. 2009; Lüdi, Höchle, and Yanaprasart 2010) that, and explain why, a management strategy fostering linguistic diversity might enhance the employees' wellbeing, and consequently the quality of their work and the overall creativity of the company. At another level, Lavric $(2007,32)$ argues convincingly in favour of the compliance factor for communicative success in an exolingual setting:

The compliance factor (...) involves adapting to the language preferences of one's partner by speaking either their mother tongue, or a language they have a very good command of and/or have a preference for. (...) Complying with the language preference of one's interlocutor is a truly polite way of acting, because it means reducing one's own negative face or (linguistic) freedom of action in order to increase that of the partner. (...) Moreover, compliance under the positive face aspect will contribute to the positive face of both partners, one of them feeling important because they are being complied with, and the other getting the image of being a kind and polite person.

The shared social representations of many interviewees confirm this experience and, thus, statements of the science of management:

Assimilation into the dominant organizational culture is a strategy that has had serious negative consequences for individuals in organizations and the organizations themselves. (...) Those who assimilate are denied the ability to express their genuine selves in the workplace; they are forced to repress 
significant parts of their lives within a social context that frames a large part of their daily encounters with other people. (Fine 1996: 494)

\section{Discussion}

Our approach to the question of English in Switzerland has been basically ethnographic, but also multimethodological, by analysing the context with demolinguistic tools, exploiting tape recordings of actual language use at work with the methodology developed by interactional linguistics, excerpting interviews and official documents with discourse analytical tools, as well as linguistic landscape with the usual instruments for this type of task. The real objective of our work was not to analyse separately the four dimensions of the DYLAN framework, but to highlight the multiple relations between them. For example, if we are interested in the way English is used at work and in the respective forms of language management, the question behind this interest is about the impact of management measures on the practice - and vice versa. In fact, our results in this aspect question firstly the "edenic" view of companies' communication policy in which the firm appears as a unique social agent controlling integrated business communication (see, for example, Bruhn 2003). In oral interactions and linguistic landscaping, not only do we observe tensions between the endoxa endorsed by the management and the actual practice; in addition, it seems that significant fractures may appear where language management is influenced by contradictory factors like corporate language vs. guaranteeing the full understanding of security messages, and where language management measures are decided at different levels of the company's hierarchy.

Due in part to the complementary approaches to the role of English in the workplace, the picture that results from our analysis is differentiated and characterized by a number of tensions. The first seems to oppose the legal framework (no mention of English, neither in the Constitution nor in the Language Law) to the "real" importance of English in the daily communication at work as documented in the national census. However, already here, things become more complicated. On the one hand, federal and cantonal legislation may differ, particularly in matters of education over which the cantons (and their coordinating body, the CDIP) have the sovereignty. On the other hand, there is a second, more general tension between legal texts (concealment of English) and the respective social representations (stressing its importance). Laws only partly reflect the ongoing discussions because they are by definition a product of the past, the manage- 
ment and use of languages being on the contrary a dynamic process. This also means that the actual behaviour does not necessarily match the guidelines, neither the legal ones nor those emanating from the companies. Thus, the choice of English in meetings at $<$ Pharma A $>$ meets the expectations set down by the guidelines. However, in Examples 3 and 4, the company's philosophy ("our corporate language is English") is put into practice in two quite different ways. Sure enough, the hierarchy plays a role. However, PW and $\mathrm{JH}$ exploit their freedom in shaping two quite different frames of participation. But they do not design it alone. As stated by Schmitt in a study about the interactive construction of hierarchies (2002, 113-114 and 131), the formal hierarchy is indeed relevant in these processes, but only in so far as it is interactively performed by all participants. JH is accommodating to his collaborators by proposing a participation frame that partly excludes him and addresses MS with a code-switching thus changing her status from a bystander to a ratified hearer - for the sake of efficiency in his team rather than for reasons of equity, as he states himself in his comment. It seems to be a habitual form of behaviour; nevertheless it has to be ratified by the other participants interactively. And the same is true for a radically different behaviour, the choice of English in the presence of the boss in the meeting of the editorial board of $<$ Pharma $\mathrm{A}>$. The result is that there are various ways of using English, from endolingual-monolingual speech among (near) native speakers over different, more or less exolingualplurilingual forms of English as lingua franca to the concurrent use of resources in multilingual speech drawing on all of the languages comprised in the interlocutors' repertoires.

Also, we have seen that social representations (the "doxa") of the company's agents are not monolithic at all, but pervaded by fractures. This polyphony is particularly striking where different voices can be identified in the discourse of one and the same person as in the following example, were TB confirms the existence of concurring agendas inside $<$ Pharma A >'s executive suite.

Well the common denominator (...) the corporate language is English especially when you are abroad it's the language that one speaks in the holding (...)

with $<$ Pharma $\mathrm{A}$ international $>$ the local languages are totally neglected so everybody speaks only English ehm practically, well I would say if I can have a meeting in German, it's like a ceremony, isn't it, because it is beautiful, and a meeting in Swiss German (sc. the local dialect) once a month at most (original interview in Swiss German) 
In the first part of the utterance, TB adopts the position of a spokesman for the company adhering to its position (you are abroad, one speaks, everybody speaks only), whilst in the second part he dissociates himself (if I can, it's beautiful) from the common knowledge, the doxa.

Finally, a similar fuzziness can be observed concerning the views and the management of linguistic diversity. At first, they reflect an additionist conception of plurilingualism that generates translation or a different language choice in a modified constellation of participants. We have found examples of that conception in the comments by agents of $<$ Agro $\mathrm{A}>$ above or in Example 2; they also underlie most questionnaires about language choice by, and linguistic competences of, multilingual persons. In many cases, however, language practices as recorded in meetings and labs are different, hybrid, essentially mixed.

Current representations of multilingualism have not accounted for all of the consequences of this fact; and plurilingual people may find themselves stuck in a web of contradictions between consciousness of social environment and the modelisation of multilingualism (Cavalli et al. 2003). At first, one must stop considering the languages practised by a sole multilingual speaker as the simple addition of languages learned on their own terms, from a monolingual perspective, and replace the classical notion of competence with that of linguistic repertoire (Gumperz 1982) or even verbal resources. ${ }^{14}$

It was Dell Hymes (1971) who, as one of the first, situated communicative competence in the practical use of language, as an ability for use: "what speakers need to know to communicate efficiently in culturally significant settings". Since this era, competence consists not only of the disposal of formal linguistic methods, but also of knowing how to enact them in an appropriate manner in a given situation (Pekarek Doehler 2005). We conceive of speakers as people who move in the world in a way that allows for the risk of stepping out of one's habitual way of speaking, where the places of language are no longer neatly contained by the political/cultural geography of speech communities (Blommaert 2005, Rampton 2010). Our data, gathered in a range of fields and analysed with a set of different methods, prompt us to place the focus on practices, resources, styles, repertoires, discourses and genres and to conceive of languages as emergent from "doing being a speaker of a language" (cf. Mondada 2004) or "languaging" (García 2008, Pennycook 2010). In following these works, we consider multilingual repertoires to be resources which are interactively mobilised in order to find local responses to practical problems (see Lüdi 
and Py 2009 for a further elaboration), and consider English to be part of these resources.

We are convinced that only a multimethodological approach that implies not only different types of data, but also a multidimensional framework for their analysis, will lead us to a much greater understanding of the increasing use and powerful role of English in all areas of the workplace.

\section{Notes}

1. Cf. http://www.dylan-project.org and Berthoud 2009.

2. In 2001, the Federal Chancellery established an English Language Service and in 2007, the task of making legislation available in English was formalised with an amendment to the Federal Chancellery Organisation Ordinance.

3. "Sie [Bund und Kantone] setzen sich im Rahmen ihrer Zuständigkeit für einen Fremdsprachenunterricht ein, der gewährleistet, dass die Schülerinnen und Schüler am Ende der obligatorischen Schulzeit über Kompetenzen in mindestens einer zweiten Landessprache und einer weiteren Fremdsprache verfügen."

4. "die Schülerinnen und Schüler entwickeln Kompetenzen der englischen Sprache"

5. The use of English is not new in Swiss universities, but it has gained in importance over the past decade. At the Federal Institute of Technology in Zurich two thirds of the Master's programmes are offered in a way that students do not need to know the local national language. In this section, the focus is on the federal level; other universities are maybe less advanced in this domain, but follow the same movement in direction of English as the preferred language of Higher Education (cf. Murray et al. 2000; Watts and Murray 2001).

6. See Lüdi and Werlen (2005) for full results.

7. We will not distinguish between these terms, but prefer the second one slightly more because it explicitly includes the multimodality of the signage in our terrains (cf. Jaworski and Thurlow 2009: „we are concerned here with the interplay between language, visual discourse, and the spatial practices and dimensions of culture, especially the textual mediation or discursive construction of place and the use of space as a semiotic resource in its own right").

8. We deliberately refrain from quantifying our pictures (mainly 384 for $<$ Pharma A $>$ in two sessions, 130 for $<$ Factory $A>$ ), every statistical intent being haphazard because we did not get equal access to the different subspaces (buildings, labs, offices, etc.) in both companies.

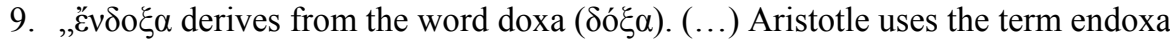
(commonly held beliefs accepted by the wise/by elder rhetors and/or by the public in general) to acknowledge the beliefs of the city. Endoxa is a more stable belief than doxa, because it has been "tested" in argumentative struggles in the Polis by prior interlocutors" (Wikipedia). 
10. "Au quotidien, on ne se rend pas compte comment on jongle avec les langues. Le but c'est vraiment de passer le message et d'être efficace. On n'a pas le temps à perdre."

11. See also Todorov (1981: 98) for whom a discourse is not homogeneous, but an "entité traversée par la présence de l'autre": "Seul l'Adam mythique, abordant avec le premier discours un monde vierge et encore non dit, le solitaire Adam, pouvait vraiment éviter absolument cette réorientation mutuelle par rapport au discours d'autrui."

12. The term 'polyphony' (or multivoicedness) was coined by Bakhtin to explain the presence of several cognitive subjects in the novels of Dostoevsky where the author, or rather narrator, acts as one participant among others in the dialogue. If we assimilate the corpus of interviews into one text, we can then find a "plurality of consciousnesses, with equal rights and each with his own world that combine but are not merged" in the unity of the communicative event (Bakhtin, 1984: 6-7). Later on, Ducrot (1984) and his French colleagues refined the notion insisting on the fragmentation of the speaker in the framework of a theory of enunciation.

13. Notice that slightly different statements can be made by the same person, in the case NK.

14. We mean by this term an open set of grammatical and syntactic (and of course mimogestual) microsystems, partially stabilised and available to the speaker as well as the interlocutor. They often stem from different varieties of a language or from various languages, as well as from diverse discourse experiences. Resources do not boil down to a dictionary of prefabricated expressions; they are shaped like semi-organised sets of often heteroclite means, similar to a handyman's toolbox. A free and active subject has amassed a repertoire of resources and activates this repertoire according to his/her needs, knowledge or whims, modifying or combining them where necessary; this happens mostly during interaction, in collaboration with (a) partner(s); as such, one can speak of shared resources.

\section{References}

Backhaus, Peter

2007 Linguistic Landscapes. A Comparative Study of Urban Multilingualism in Tokyo. Clevedon et al.: Multilingual Matters.

Bakhtin, Mikhail

1984 Problems of Dostoevsky's Poetics. Edited and trans. by Caryl Emerson. Minneapolis: University of Michigan Press. 
Ben-Rafael, Eliezer, Elana Shohamy, Muhammad Hasan Amara, and Nira Trumper-Hecht

2004 Linguistic Landscape and Multiculturalism: A Jewish-Arab Comparative Study. Tel Aviv: Tami Steinmetz Center for Peace Research.

Berthoud, Anne-Claude

2009 Le projet DYLAN 'Dynamiques des langues et gestion de la diversité.' Un apercu. Sociolinguistica 22: 171-185.

Blommaert, Jan

2005 Discourse: A critical introduction. Cambridge: Cambridge University Press.

Böhringer, Heike, Cornelia Hülmbauer, and Barbara Seidlhofer

2009 DYLAN working Paper 4 on "Creativity and Innovatio", RT 4.2. University of Vienna.

Bruhn, Manfred

2003 Integrierte Unternehmens- und Markenkommunikation. Strategische Planung und operative Umsetzung. 3. Aufl. Stuttgart: SchäfferPoeschel Verlag.

Calvet, Louis-Jean

1990 Des mots sur les murs: Une comparaison entre Paris et Dakar, In Des langues et des villes, Robert Chaudenson (ed.), 73-83. Paris: Agence de coopération culturelle et technique.

Cavalli, Marisa, Daniela Coletta, Laurent Gajo, Marinette Matthey, and Cecilia Serra (eds.)

2003 Langues, bilinguisme et représentations sociales au Val d'Aoste. Aoste: IRRE-VDA.

Ducrot, Oswald

$1984 \quad$ Le dire et le dit. Paris: Editions de Minuit.

Fine, Marlene G.

1996 Cultural Diversity in the Workplace: The State of the Field. Journal García, Ofelia of Business Communication 33 (4): 485-502.

2007 Intervening discourses, representations and conceptualizations of language. Foreword. In Disinventing and reconstituting languages, Sinfree Makoni, and Alastair Pennycook (eds.), xi-xv. Clevedon: Multilingual Matters.

2008 Bilingual Education in the 21st Century: A Global Perspective. Oxford: Wiley-Blackwell.

Goffman, Erwing

1981 Forms of Talk. Philadelphia: University of Pennsylvania Press. Gumperz, John

1982 Discourse strategies. Cambridge: Cambridge University Press.

House, Juliane

2003 English as a lingua franca: A threat to multilingualism? Journal of Sociolinguistics 7 (4): 556-578. 
Hymes, Dell

1971 On communicative competence. Philadelphia: University of Penn-

Jakobson, Roman sylvania Press.

1960 Linguistics and Poetics. In Style in Language, Thomas Sebeok (ed.), 350-377. Cambridge, MA: MIT Press.

Jaworski, Adam, and Crispin Thurlow (eds.)

2009 Semiotic Landscapes: Language, Image, Space. London : Continuum.

Jenkins, Jennifer

2007 English as a Lingua Franca: Attitudes and Identity. Oxford: Oxford University Press.

Kerbrat-Orecchioni, Catherine

1992 Les interactions verbales, vol. 2. Paris: A. Colin.

Knapp, Karlfried, and Christiane Meierkord (eds.)

2002 Lingua franca communication. Frankfurt am Main: Peter Lang.

Landry, Rodrigue, and Richard Y. Bourhis

1997 Linguistic landscape and ethnolinguistic vitality: an empirical study.

Lavric, Eva Journal of Language and Social Psychology 16 (1): 23-49.

2007 Code choice and face. Lodz Papers in Pragmatics 3: 23-35. Lüdi, Georges

2007 Basel: einsprachig und heteroglossisch. Zeitschrift für Literaturwissenschaft und Linguistik 148: 132-157.

2010 L'analyse du paysage linguistique comme instrument pour analyser la gestion des langues dans les entreprise. In Le plurilinguisme au travail entre la philosophie de l'entreprise, les représentations des acteurs et les pratiques quotidiennes, Georges Lüdi (ed.), 87-106. (Acta Romanica Basiliensia 22.) Basel: Institut für Französische Sprach- und Literaturwissenschaft.

Lüdi, Georges, Lukas A. Barth, Katharina Höchle, and Patchareerat Yanaprasart

2009 La gestion du plurilinguisme au travail entre la "philosophie" de l'entreprise et les pratiques spontanées. Sociolinguistica 23: 32-52.

Lüdi, Georges, Katharina Höchle, and Patchareerat Yanaprasart

$2010 \quad$ Plurilingual practices at multilingual workplaces. In Multilingualism at work, Birgit Apfelbaum, and Bernd Meyer (eds.), 211-234. Amsterdam: John Benjamins.

Lüdi, Georges, and Bernard Py

2009 To be or not to be ... a plurilingual speaker. International Journal of Multilingualism 6 (2): 154-167.

Lüdi, Georges, Iwar Werlen, and Rita Franceschini et al.

1997 Le paysage linguistique de la Suisse. Berne: Office Fédéral de Statistique (Statistique de la Suisse. Recensement fédéral de la population 1990). 
Lüdi, Georges, and Iwar Werlen et al.

2005 Le paysage linguistique en Suisse. Neuchâtel: Office Fédéral de Statistique (Statistique de la Suisse. Recensement fédéral de la population 2000).

Murray, Heather, Ursula Wegmüller, and Fayaz Ali Khan

2000 Englisch in der Schweiz. Forschungsbericht. Zu Handen des Bundesamtes für Bildung und Wissenschaft und der Paritätischen Arbeitsgruppe Sprachengesetz Bund/Kantone (PAS). Bern: Institut für Sprachwissenschaft der Universität Bern.

Mauranen, Anna, and Elina Ranta (eds.)

2009 English as a lingua franca. Studies and findings. Newcastle upon Tine: Cambridge Scholars.

Mondada, Lorenza

2004 Représentations, stéréotypes, catégorisations: de nouvelles voies pour la sociolinguistique et la linguistique de l'acquisition? In Un parcours au contact des langues. Textes de Bernard Py commentés, Laurent Gajo, Marinette Matthey, Danièle Moore, and Cecilia Serra (eds.), 257-261. Paris: Didier.

Oesch-Serra, Cecilia, and Py, Bernard

1997 Le crépuscule des lieux communs, ou les stéréotypes entre consensus, certitude et doute. Tranel 21: 29-49.

Pekarek Doehler, Simona

2005 De la nature située des compétences en langue. Repenser l'enseignement des langues: comment identifier et exploiter les compétences? Jean-Paul Bronckart, Elena Bulea, and Michèle Pouliot (eds.), 41-68. Villeneuve d'Ascq: Presses universitaires du Septentrion.

Pennycook, Alastair

2007 Global Englishes and transcultural flows. Abigdon, and New York: Routledge.

2010 Language as a local practice. London: Routledge.

Pitzl, Marie-Louise

2009 We should not wake up any dogs: Idiom and metaphor in ELF. In English as a Lingua Franca. Studies and findings, Anna Mauranen, and Elina Ranta (eds.), 298-322. Newcastle upon Tyne: Cambridge Scholars.

Rampton, Ben

2010 From 'multi-ethnic adolecent heteroglossia' to 'contemporary urban vernaculars'. Working Papers in Urban Language and Literacies, 61. http://www.kcl.ac.uk/schools/sspp/education/research/groups/llg/wp ull41.html 
Rosenbaum, Yehudit, Elizabeth Nadel, Robert L. Cooper, and Joshua A. Fishman

1977 English on Keren Kayemet Street. In The Spread of English: The Sociology of English as an Additional Language, Joshua A. Fishman, Robert L. Cooper, and Andrew W. Conrad (eds.), 179-196.

Schmitt, Reinhold Rowley MA: Newbury House.

2002 Hierarchie in Arbeitsgruppen als stilbildender Aspekt. In Soziale Welten und kommunikative Stile, Inken Keim, and Wilfried Schütte (eds.), 113-135. Tübingen: Narr.

Seidlhofer, Barbara

2006 Towards making 'Euro-English' a linguistic reality. In World Englishes. Critical Concepts in Linguistics, Kingsley Bolton, and Braj B. Kachru (eds.), vol. III, 47-50. London: Routledge.

Shohamy, Elana, and Durk Gorter

2008 Linguistic landscape: expanding the scenery. New York: Routledge.

Spolsky, Bernard, and Robert L. Cooper

1991 The Languages of Jerusalem. Oxford: Clarendon Press.

Todorov, Tzvetan

1981 Mikhail Bakhtine, le principe dialogique. Paris: Seuil.

Watts, Richards J., and Heather Murray (eds.)

2001 Die fünfte Landessprache? Englisch in der Schweiz. Zürich: vdf. 